\title{
EXCURSION TO SWANAGE, LULWORTH COVE, AND BOURNEMOUTH.
}

\author{
Whitsuntide, May i4th to i8Th, igio. \\ Directors : F. Hovenden, F.L.S., F.G.S., H. W. Monckton, \\ F.L.S., F.G.S., Dr. W. Theophilus Ord, and A. Smith \\ WOODWARD, LL.D., F.R.S., F.L.S., F.G.S. \\ Excursion Secretary: W. P. D. Stebbing. \\ (Report by THE DIRECTORS.) \\ PART I.-By Mr. HOVENDEN.
}

THE party (some 55 members and friends) assembled at Swanage

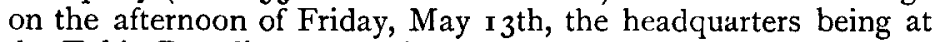
the Tokio Boarding House in Rempstone Road.

\section{Saturday, May r4th : Lulworth Cove. \\ Director: Mr. HOVENDEN.}

The members walked to Peveril Point and examined the Upper Purbeck Beds. The Purbeck Marble first attracted attention, and the Unio Beds were then examined, some good specimens of Unio being seen. The members then made their way along the shore to see the small fault shown in the diagram Fig. 38, p. 520 , and ascended the cliff by a path in Durleston Bay.

The party then proceeded to Swanage Pier and embarked or Lulworth. The boat started at 10.45 a.m. and made an excellent passage with a smooth sea. At the request of the Director the captain kept close in to the coast, so as to give the members an opportunity of seeing the grand coast scenery. The various localities and formations were pointed out as the boat passed. The party arrived at Lulworth a little before one o'clock, and on landing walked in a westerly direction to inspect the remarkable section at Stair Hole (see Pl. XXXVII, Fig. I). After a short halt, during which the Director pointed out the more important features of the section, the walk was continued westwards to Man-of-War Cove. On the way Mr. Whitaker drew attention to the various divisions of the Cretaceous Series, the lower beds of which are at a very high angle, becoming gradually vertical, and end in the Chalk being actually inverted.

The members lunched on the beach of Man-of-War Bay, and the Director drew attention to the vertical strata in the cove at 
the west end of the bay, and mentioned that there was amongst them a remarkable example of a vertical ripple-marked stratum.

The greater number of the members then crossed the promontory at the end of the bay, viewed the very curious and interesting hole in the rocks known as Durdle Door, and proceeded to collect fossils from the Upper Greensand in the cliff. The line of hollows in the Chalk cliff which mark a nearly horizontal thrust fault was pointed out. They are shown in the sketch reproduced as Fig. 179, page I8z of Dr. Strahan's "Geology of the Isle of Purbeck." The party then walked back to Iulworth Cove, and proceeding in an easterly direction, cxamined the broken-beds and the vertical strata at the entrance of the Cove. The members then walked along the top of the cliff to Mupe Bay, where they descended the somewhat steep cliff and examined the Portland and l'urbeck beds exposed on the shore.

The Director drew attention to a ledge covered with fossil oyster-shells, to the fine specimen of ripple-marked stone over the fossil shells, and to the vertical strata at the western end of Mupe Bay.

After inspecting the rocks on the shore, the members climbed up the cliff and walked back along the top to a point from which the fossil forest could be seen. 'l'he Director remarked that it is situated on a ledge where it has become exposed by the weathering of the superimposed layers. Below the fossil forest the cliffs rise vertically from deep water, there being no shore, and in consequence the waves during storms have immense power and have exposed the ledge. One of the trees, with its matrix, has been removed to a distance from its original position by the waves, broken in half, and one half carried to a considerable distance. Between the fossil trees, he said, the rock is often ripple-marted, showing the placid way in which they must have gone beneath the water. He considered that the forest extended beneath the surface of the ground for miles, since what is apparently the same forest formation is found at Portishan, where it was examined by the Association on April 9th, I8g8 (Proc. Vol. xv, page 298), and that place is fifteen miles northwest of Lulworth. 'The fossil trees are largely eroded, but he considered that there was sufficient evidence of their being actual trees in the silicified remains which form a core to the concentric mastrix of carbonate of limc. Between the fossil forest and the chalk downs are the various formations from the Purbeck to the Chalk, all squeezed into a very small space, as had been seen in Lulworth Cove with its more or less vertical layers. The Director continued to observe that in no other part of the country can there be shown a chapter in the history of earth-movements revealing the history of life so well as in this place. It is, he said, a chanter' in Nature's great stone Bible, 
which it is the privilege of Geology to interpret, and it is when we consider the immense time required to account for these movements, a time which is to the human mind that of Eternity, that we appreciate the grand science of Geology. But this science is incomplete. We, he added, want to know the physical causes which have contorted the layers into the various forms shown. This can only be done when we abandon the metaphysical or mystical order of thought, so prevalent at the present time and so injurious to progress, and afterwards find out the fundamental power which produces erosion; this can be done by experiment. Then Geology will be as far as possible a complete science, and all which can be learnt in the future will be merely detail.

Most of the members then descended to the ledge in the cliff on which the fossil trees are found (see Pl. XXXVII, Fig. 2), and made a careful examination of them, attention being drawn to the specimens figured in Dr. Strahan's "Geology of the Isle of Purbeck," Pl. II and Fig. I 28.

The members then walked back to Lulworth and embarked at 6.15 for Swanage. The sea was found to be much rougher than on the outward voyage, but the members proved to be good sailors and seemed to enjoy the motion. Swanage was reached at about 8 o'clock, thus ending a most instructive and enjoyable day.

\section{PART II.-By Mr. MONCKTON.}

\section{Monday, May i6th, i910: Chapman's Pool and St. Alban's HEAD.}

Director: Mr. MONCKTON.

THE party left Swanage at $9.30 \mathrm{a} . \mathrm{m}$. and drove to the little village of Worth Matravers, four miles to the west. From Worth the party walked to the seashore at Chapman's Pool and proceeded to collect fossils from the Kimmeridge Clay. The fossils are very abundant and not ill-preserved, but they are for the most part crushed, and the Director expressed the opinion that this was due to the fact that they became covered by the marine deposit of mud before the animal matter had decayed. In support of this view he pointed to the larger Ammonites, which, owing to their size, were longer in being buried than the smaller shells, and in their case the outer chamber had become filled with mud and consequently is not crushed, whilst the inner chambers into which the mud had not penetrated have been flattened. Mr. Ll. Treacher found some specimens which he believes to be Belemnites souichii, a species which Hudleston said "may 
Proc. Geol. Assoc., Vol. XXI.

Plate XXXViI.

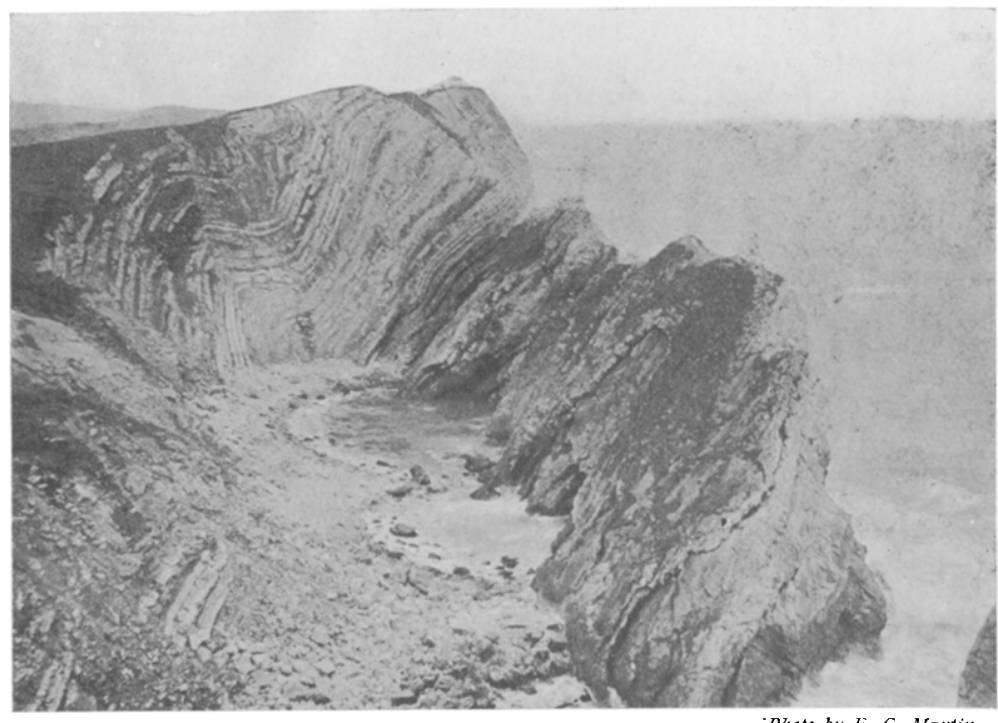

Fig. i.-Stair Hole, Lulworth.

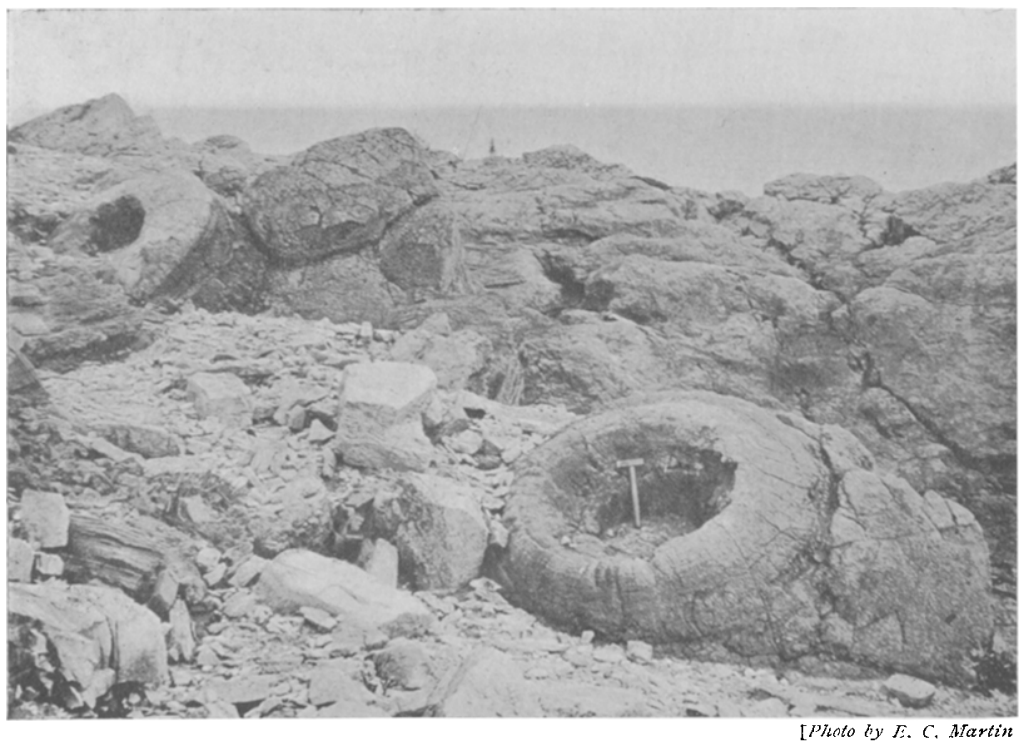

Fig, 2.-The Fossil Forest, Lulworth. 
be expected at Chapman's Pool" (Proc. Geol. Assoc., vol. xiv, p. 3I6). Leaving the shore the members walked along the coastguard's path towards St. Alban's Head, and during a short halt the Director gave an account of the strata shown in the beautiful coast section before them. The succession is shown in Fig. 36. At the top of St. Alban's Head there is a thin covering of Lower Purbeck Beds. Below is the Portland Stone, with a thickness of about $\mathrm{I} z 0$ feet and well shown in the cliffs. Below it we get the Portland Sand, a sandy marl with cement-stones, which gradually becomes shaly and passes down into the Kimmeridge Clay. This last is much hidden by landslips at St. Alban's Head, but is very well seen in the cliff section at

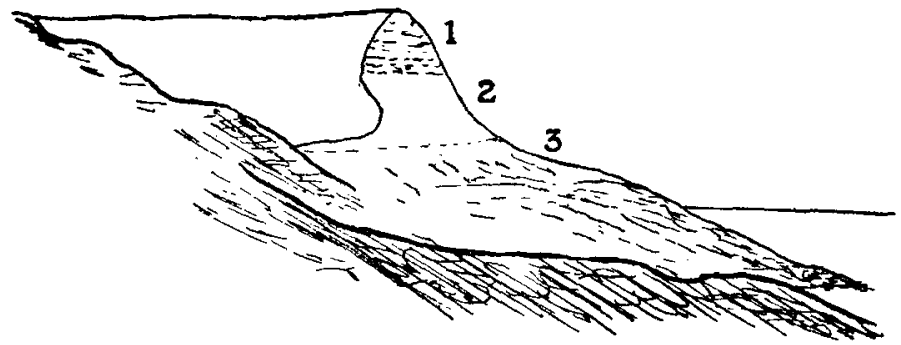

Fig. 36.-St, Alban's Head from Chapman's Pool.o- $H$ ll. Monckton.

I. Portland Stone (with thin Purbeck Beds at top).

2. Portland Sand.

3. Kimeridge Clay (much hidden by slips from above).

Chapman's Pool. The exact point at which the division between the Portland Sand and the Kimmeridge Clay should be placed is a matter of doubt. Fitton placed it at the point where the little valley named Pier Bottom cuts the cliff (Trans. Geol. Soc., Vol. iv, Part 2,1836 , page $2 \mathrm{II}$ and Pl. X b), and he is followed by the Geological Survey ("The Geology of the Isle of Purbeck, etc.," I 898, PI. XI). There is a further doubt whether the Geological Survey are right in classing the more clayey beds below with the Kimmeridge Series, or whether they are not more correctly classed with the Portland Beds and the equivalent of the Swindon and Hartwell Clays. The question has been discussed by Hudleston (Proc. Geol. Assoc. Vol. xiv (1896), page 322 ).

The members walked up the grassy slope from Pier Bottom to St. Alban's Head and halted there for a short time to inspect the interesting little Norman Chapel, after which the walk was continued along the top of the cliff to the large quarry at Winspit, where a halt was made for luncheon. The Director 
explained that the Portland series of the cliffs from St. Alban's Head to Durleston Head consisted of the following beds :-

(a) A limestone forming a well-marked white band about 9 feet. This is the "Shrimp Bed."

(b) One, or more often two beds, of stone more or less full of Perna and known as the Perna-Bed. About 10 feet.

(c) Limestone of variable thickness, say 7 feet.

(d) A cherty or flinty bed, also variable, about 4 feet.

(e) The stone beds which have been largely worked in the cliffs and in the adjacent quarries, about 19 feet.

(f) The Chert Beds, over 60 feet, often with bands free from chert, which latter have been worked in places.

There are about four feet of Lower Purbeck Beds at the top of Winspit Quarry and below them the white Shrimp Bed is very conspicuous, and is clearly seen in the photograph reproduced on Plate XXXVIII (Fig. I). It is Bed 2 in Fig. 37. The Perna Bed (3) is well developed and big blocks from it lie about the workings. Below are the stone beds, 4 of Fig. 37 , in the middle

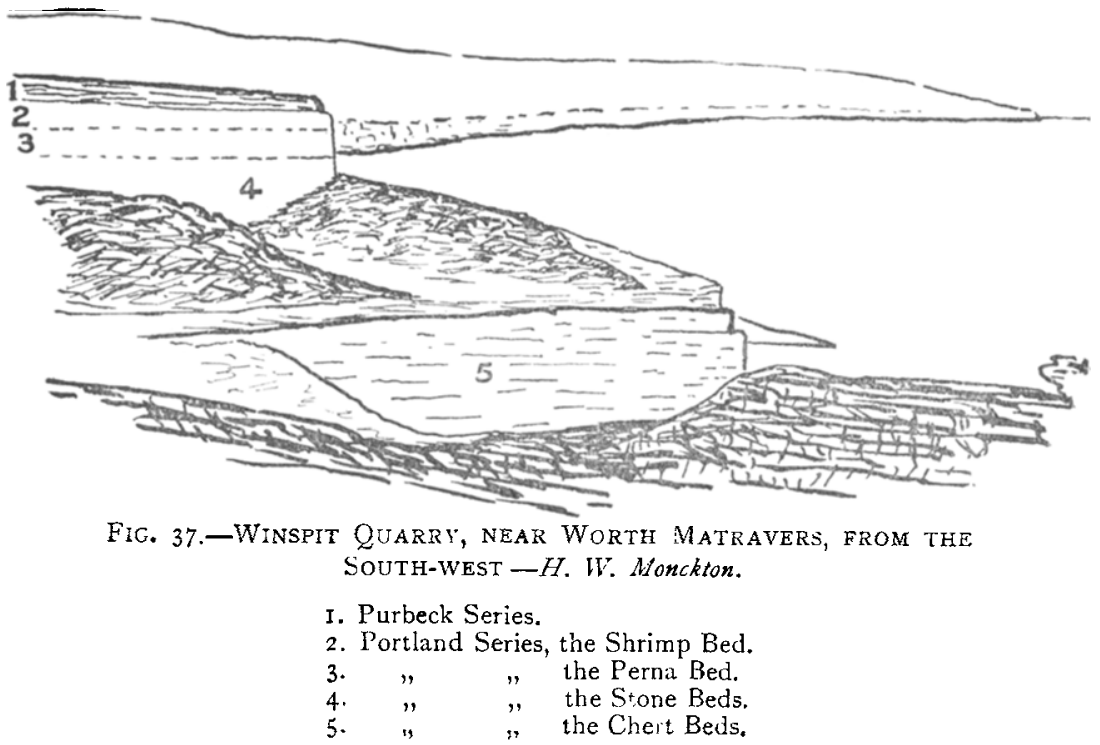

of which are some bands of chert. The lower part of this bed, i.e., below the chert bands, has been worked underground. The main chert beds, 5 of Fig. 37 , form the cliff in the foreground of the photograph (Plate XXXVIII, Fig. I), and they also spread out as a wide ledge below high-water mark.

A similar succession was pointed out at various quarries as the party made their way along the top of the cliff towards Swanage, and a long halt was made at the Dancing Ledge Quarry. 
(Plate XXXVIII, Fig. 2). At the western end of that quarry the members were able to examine both the "Shrimp Bed" and the "Perna Bed" in sitî, and subsequently the Director pointed to a large mass of the "Shrimp Bed" which had fallen and was in an excellent condition for the collector. From this mass many fossils were obtained, and Mr. 'Thatcher found a good specimen of the "Shrimp" itself, which he kindly handed to the Director. It has been deposited in the Natural History Museum. IDr. Bather describes the specimen as a chela of a Crustacean, one of the Macrurous Decapoda, probably Eryma or Glyphea. He adds that the species does not appear to have been described.

Whilst some members of the party were collecting from the Shrimp Bed, the President made an examination of the Chert Beds, which are well seen at the Dancing Ledge.

The members then walked back to Swanage.

\section{Studland Bay.}

Eirector: Mr. MONCKTON.

During the stay of the Association at Swanage some of the members availed themselves of an opportunity to visit Studland. On leaving the Hotel the party walked to the shore and inspected the Section of the Wealden Beds shown in the cliffs of Swanage Bay.

The Director remarked that, as mentioned in the Memoir on the Isle of Purbeck (Mem. Geol. Survey, I898), the junction of the Wealden Beds and Purbeck Beds is concealed at Swanage by alluvium, but that there was at the moment a very interesting little section in the town on the northern side of the street leading from Swanage Station to the sea. It showed some ten feet of reddish clay with an apparent dip to the north. That section must be very near the bottom of the Wealden Beds. Turning to the cliff before them he pointed out the bed of quartz grit marked on the geological map, and the members then walked along the shore towards the Chalk cliffs. After a time a path to the top of the cliff was taken, and a halt was called on reaching Punfield Cove.

The Director made a few remarks on the Punfield controversy, and pointed out the position of the various beds. A large landslip had prevented the section being very clear at the time, but Mr. Treacher found a block of the fossiliferous limestone termed by Prof. Judd the Marine Band.

Mr. R. D. Oldham observed that this landslip was a very pretty model, showing on a small scale all the features exhibited on a large one by a great mountain landslip. At the head was a low cliff marking the line of the separation fissure which cut off the region of removal whence a mass of earth had 
slipped. Then there was the well-defined channel down which the sliding mass had moved, with its scoured and striated sides. Finally, there was the region of deposition where the moving mass had come to rest, in which were well illustrated the steep slopes of the outer side, the roughly concentric ridges due to the compression set up by the momentum of the moving mass as it was brought to rest, and finally the way in which the highest part of the slip was at the edge, leaving a depression behind it, in which a small pool of water represented one of the shallow lakes often found in similar situations on a great landslip.

Continuing their way northwards the members made a short examination of the Upper Greensand as exposed near the top of the cliff, and then walked to Ballard Down and halted at a barrow from which they had a fine view of Studland Bay with Poole Harbour and the Bournemouth cliffs.

The Director remarked on the number of barrows which were found not only on the Chalk Downs, but also on the Eocene heathland, and he thought that there must have been a considerable population in the district in early times.

The party then walked to the shore at Studland Bay and made a careful examination of the junction of the Chalk with the Reading Beds. The top of the Chalk is very irregular; the irregularity is not, however, due to pre-Eocene erosion, but to the underground decay of the Chalk, and in one place the cliff seems to cut through a swallow hole. The bottom of the Reading Beds is formed of ferruginous grit with a conglomerate of flint pebbles and black unworn flints. At the top of the cliff blue and red sand is to be seen capping the Chalk for some distance.

The Reading Beds are succeeded by London Clay, and a stiff grey clay was seen by the Director some time ago a little south of the Warren, but the formation is almost hidden by vegetation. The Bagshot Beds come on at the point where a lane reaches the shore on the north of the Warren. Both the Reading Beds and the London Clay dip northwards at a rather high angle and it is not easy to estimate their thickness. The bore hole at Bovington Camp, which has been described by Hudleston (Proc. Dorset Field Club, vol. xxviii, 1907, p. 185 and "Geology in the Field," p. 373), is a useful guide to the thickness of the Eocene beds in the district, and it gives a thickness of I $_{5}$ feet for the London Clay and Reading Beds. Hudleston did not separate them, but possibly his bed 24, coarse sand and pebbles 5 feet, should be taken as the basement bed of the London Clay, giving a thickness of 87 feet to the London Clay and of 28 feet to the Reading Beds. The Director said that he had seen very few sections in the Reading Beds in the Isle of Purbeck; there was, however, one fair section in a brickfield at Coombe Keynes showing- 
r. Sand false-bedded of a buff colour with traces of red in places.

2. Reddish sandy clay not unlike the mottled clay of the London District.

The members after inspecting the junction of the Chalk with the Reading Beds, walked along the shore towards the north and inspected the cliff of Bagshot Beds, a part of which is shown in the photograph reproduced on Plate XXXVIII, Fig. 4 . In the upper part of the cliff are some layers of clay, but the greater part is formed of sand, yellow and orange in colour, with crimson patches. The sand is very ferruginous in places and some big blocks of iron-sandstone are shown in the photograph lying on the shore.

North of Studland the shore is formed of Blown Sand, and the party seated themselves on the sandhills for luncheon. After luncheon the members walked some way along the shore to inspect the sandhills and the Little Sea, a lagoon formed behind them, and then returning to Studland walked on to the heath on the north-west of that place. A small brickfield where the Bagshot clays are worked was seen, but the section was not in a condition to deserve a close examination, and the members walked across the heath to the Puckstone, which is a mound apparently consisting mainly of iron sandstone. On one side a digging has at some time been made in it, possibly under the mistaken impression that it was a barrow. After a short halt the members proceeded to the much more imposing Agglestone, a photograph of which is reproduced as Plate XXXVIII, Fig. 3. It might easily be mistaken for an erratic or perched block, but in fact it is in situ, and an excellent example of the concretionary sandrock which occurs in the Bagshot Beds here, specimens of which had already been noticed by the members lying on the shore in Studland Bay. The cementing material is apparently ferruginous, in any case, as Hudleston cautiously observes, "to a considerable extent ferruginous" ("Wareham and its Points of Interest." Bournemouth, preface dated April i 900, p. 36). He remarks that "the stone appears to have acted just as a perched block might have done in partially protecting the immediately subjacent sands from atmospheric waste, so that in the sculpture of the district by the ordinary agents of erosion it has been left on a kind of mound of its own making." The photograph, Plate XXXVIII, Fig. 3, was taken with a view to show the mound and the manner in which it and the protecting mass stand out above the heath. Poole Harbour is seen in the distance on the left, and Boumemouth cliff on the right of the photograph. Some of the party climbed to the top of the Agglestone and descended, not without difficulty, and the party then walked back to Swanage across the Downs, but by a different path from that taken on the way out. 
PART III.-By Dr. ORD.

Tuesday, May i ith : Bournemouth.

Director: IR. ORD.

The party left Swanage Pier at 9.20 a.m., by steamboat, for Bournemouth. The very fine section shown by the Chalk cliffs at the eastern end of Ballard Down, with the Isle of Purbeck thrust fault, were very well seen from the deck as the boat passed. (See "Geology in the Field," Fig. 70, p. 4ro.)

The party were received at Bournemouth Pier by Dr. Ord and several members of the Bournemouth Natural Science Society. Proceeding up the East Cliff, a halt was called at the top of the zigzag path and the Director gave a brief sketch of the geology of Bournemouth Bay. As Chairman of their local Natural Science Society, Dr. Ord welcomed the Association to Bournemouth, He reminded them that a distinguished member of the party had honoured the Bournemouth Natural Science Society by accepting its presidency for this year, and they were all glad to see Dr. Smith Woodward amongst them that day. Turning seaward, Dr. Ord pointed out the line of Chalk hills-the Purbeck Hills--which in recent geological times were continuous with the Needles and the Chalk axis of the Isle of Wight. When the sea broke through these Chalk Downs it rapidly washed out the soft Tertiary strata behind, and so formed Bournemouth Bay. These Tertiary strata had been laid down by a great river which flowed from the west, and must have been as great as the Ganges or the Amazon, and drained a vast country which included parts of Devon and Cornwall; but most of it had now vanished beneath the sea. The existing River Frome, which emptied into Poole Harbour, was a degenerate descendant of this old river, which formerly flowed through the Solent and entered the Channel somewhere beyond Selsey Bill. The Hampshire basin should be compared with the London basin, both being bounded by Chalk hills, and containing beds of Tertiary age which had been deposited by a great river in geological times. The spot on which they stood was approximately the centre of the Hampshire area, and was bounded on the south by the Chalk hills of Purbeck and the Isle of Wight, and on the north by the Chalk Downs of Dorset, Wiltshire, and Hampshire. Turning to the face of the cliff, they saw they were standing on a surface of Blown Sand, beneath which was Plateau Gravel. Next came the Boscombe Sands, which were the lowest beds of the Bracklesham in this district; the rest of the cliff to the shore was composed of Bagshot Beds, the Marine Series above and the Fresh-Water beds lowest of all.

At the conclusion of the Director's address the party descended to the Undercliff Drive, where he pointed out various features of 
Proc. Geol. Assoc., Vol. XXI.

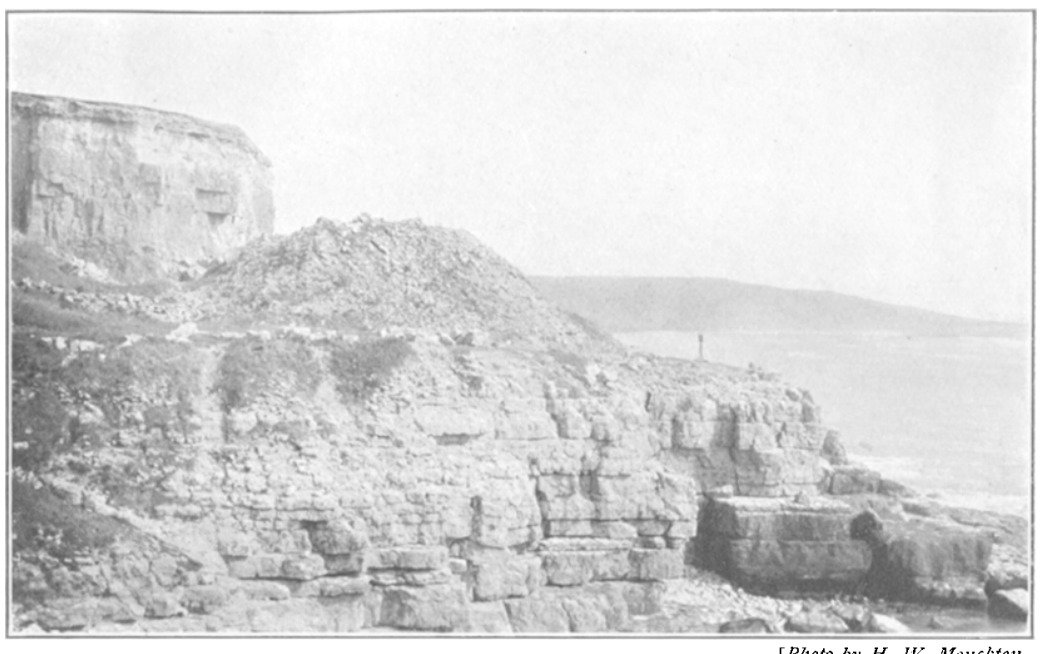

Fig. I.-Winspit Quarry, from the North-West.

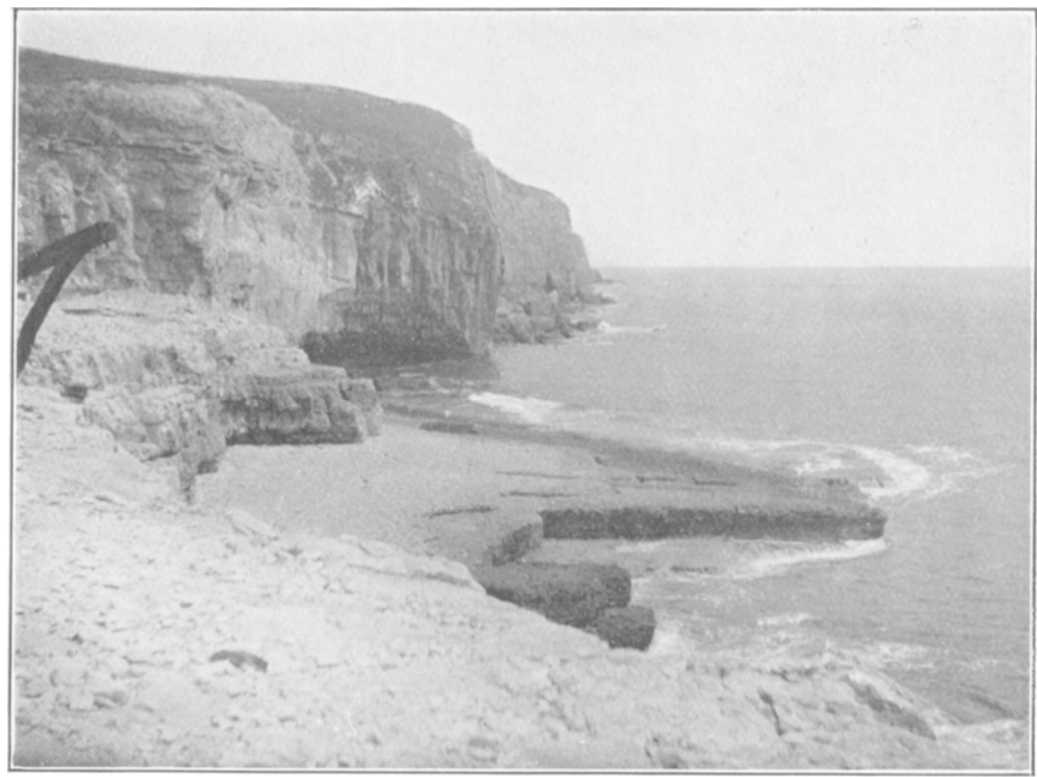

[Photo by H. H. Nonchton.

Fig. 2.-DANCING LEDGE, From THE West.

To face page 518. 


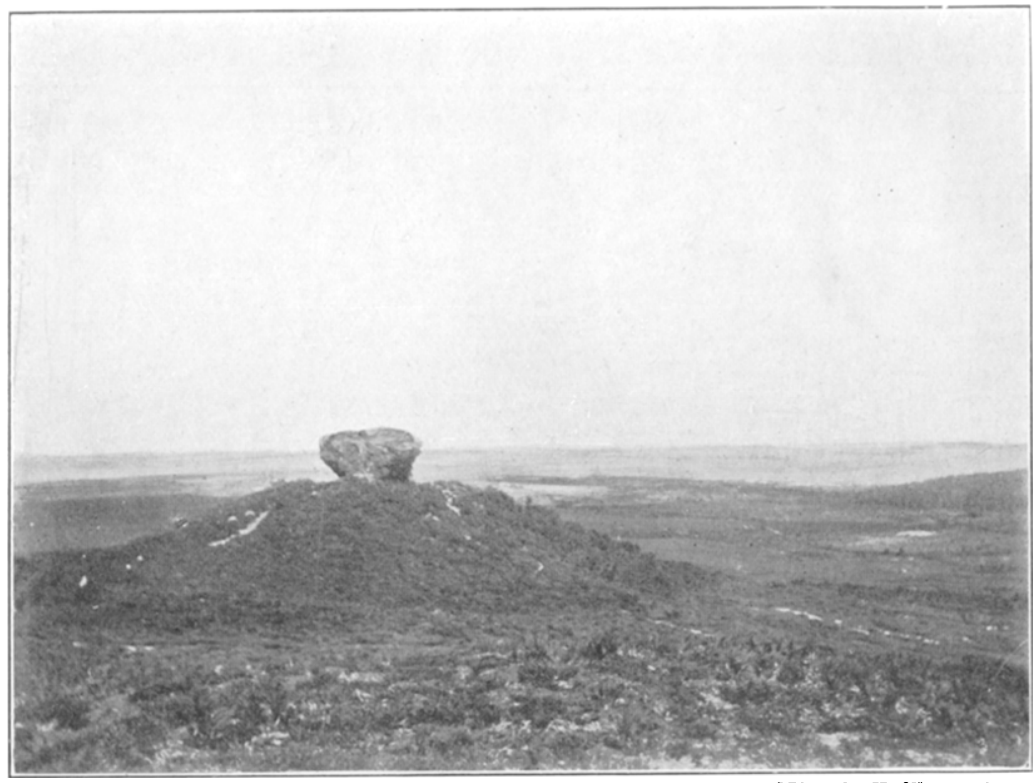

[Photo by H.W., Morchton.

Fig. 3.-The Agglestone, from the South-West.

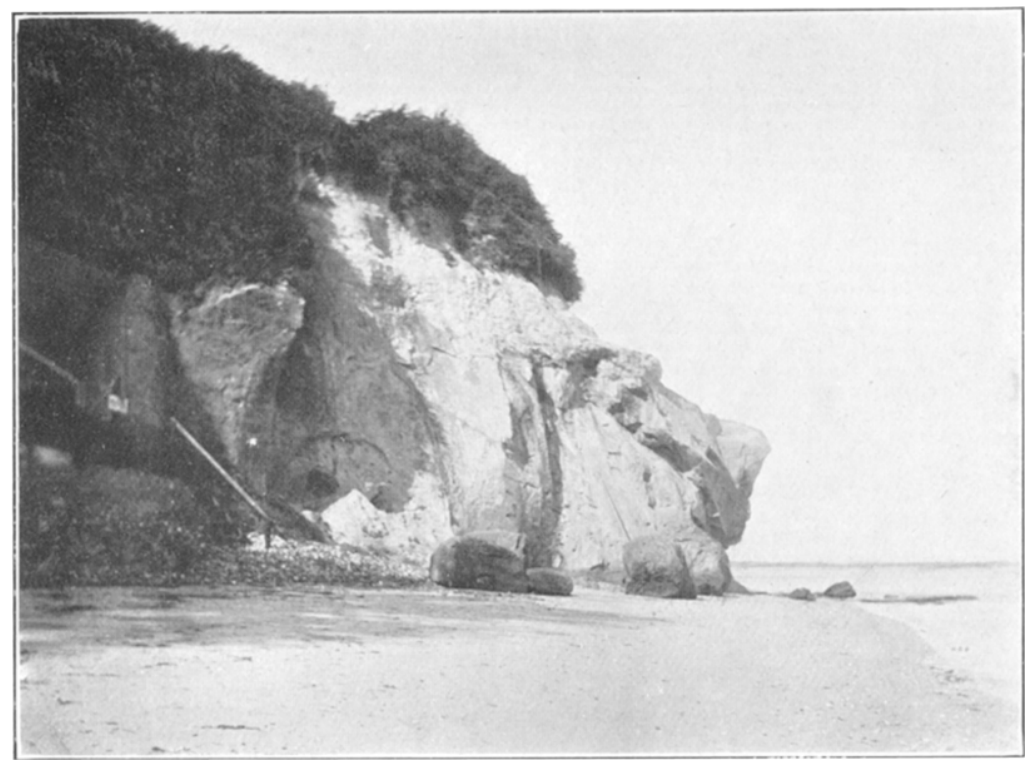

Fltoto by H. W. Moreckton.

Fig. 4.-Cliff of Bagshot Beds, Studland, from the South-East. 
geological interest in the cliffs and explained the nature and mode of occurrence of the celebrated leat-beds. The walk was continued along the beach to Boscombe, beds of "rolled leaves" redeposited in sand being shown; and the "seed patch," where some fifteen varieties of seeds of semi-tropical plants have been found, specimens of which were exhibited by Dr. Ord, also the broken character of the beds, and their "current bedding" in places-showing the action of tides and storms in the estuary of this old river in long-past ages - were all noted with interest. At Boscombe Chine the remarkable example of "wind denudation" exhibited on the west face of the cliff was pointed out. Next the party visited Honeycombe Chine, by kind permission of $\mathrm{Mr}$. George Hamilton, of Boscombe Place, on whose property this most interesting of all the local chines is situated. The geological features of the chine having been explained, a search was made for "nipas fruits" in a spot indicated by the Director. Some fine specimens were soon obtained, though their fragility rendered it doubtiul if they could be preserved. It was explained that these fruits were produced by plants which grew in vast numbers in the black mud of tropical rivers near their mouths, and the fruits floating down gradually sank and became deposited in the mud-flats and sand-banks. 'Thus they had been preserved in the beds near the mouth of this old geological river, to be unearthed by the geologists of to-day.

The members continued their walk towards Southbourne. At Fisherman's Walk some exertion was saved by taking the tram to the Cross Roads, whence Hengistbury Head was reached, and luncheon was enjoyed on the grassy slopes of the Double Dykes. Aiterwards hearty votes of thanks were passed to $\mathrm{Mr}$. Hovenden, Mr. Monckton and Dr. Ord, who by their able directorship of the various excursions had so contributed to the interest of the visit. The cliffs at Hengistbury Head were next explored, their geological features being pointed out by Dr. Ord, who exhibited a coloured chart illustrating the subject. Fossils were next sought for, and some shark's teeth and various tree remains were soon obtained. Returning by tram to Bournemouth, an excellent tea was provided by the local Society at Gervis Hall Restaurant. Some of the party then proceeded to Durley Chine, where the large sandstone blocks seen in situ were explained to show the formation of the well-known Sarsen Stcnes, found on the surface of land whence Tertiary Beds have been denuded. Thence Bournemouth Pier was reached at 6 p.m., and the return boat for Swanage carried off the visitors. So ended a very pleasant and instructive day, which had included a study of many matters of great geological interest and novelty, especially to those members who had not examined the Bournemouth Cliffs previously. 
PART IV.-By Dr. SMITH WOODWARD.

WEDNESDAY, MAY I8TH, DURLESTON Bay and THE Swanage Stone QUARRIES.

Directors: Mr. Hovenden and Dr. WOONWARD.

The morning was spent in a detailed examination of the series of Upper, Middle and Lower Purbeck Beds in Durleston Bay. Aided by a diagrammatic section prepared and distributed by Mr. James Parker, the party began the walk along the beach at Peveril Point, and noted the stratigraphical sequence and the faults as far as the zigzag path up the cliff. The marly mammal bed was discovered at two points, and was worked in vain for mammalian fossils. A slab of hard limestone on the beach was observed to be marked by a large footprint of Iguanodon. Before ascending by the zigzag path Dr. Woodward made some remarks on the vertebrate fossils of the Purbeck Beds, especially emphasising the dwarfed character of many of the fishes, some of the crocodiles, and all the mammals. The mammals, which appeared to be insectivorous or carnivorous marsupials, were probably mere "escapes" from some land where their race was flourishing, and did not give much idea of the characteristic Upper Jurassic mammalian fauna. After Durleston Bay, the Tilly Whim caves were visited, and special attention was paid to the Polyzoa in the Portlandian oyster-bed, from which a good collection was obtained. Amongst them $\mathrm{Mr}$. 
Ll. Treacher records specimens of Berenicea porllandica. On the return in the afternoon Mr. Collins met the party and conducted them to one of the quarries on the hillside above Swanage. The mode of working the Purbeck stone was explained, and several members entered the underground galleries.

This concluded the Whitsuntide Excursion, and most of the members left Swanage in the course of the afternoon.

\title{
REFERENCES.
}

Geological Survey Map, New Series, Sheets 329, 342, 343.

I 896. "Excursion to Swanage." Reports by H. W. Monckton and W. H. Hudleston. Geol. Proc. Assoc., vol. xiv, pages 307-324.

18g6. Strahan, A.--"Physical Geulogy of Purbeck." Proc. Geol. Assoc., vol. xiv, p. 405 .

I898. Strahan, A.- "The Geology of the Isle of Purbeck, etc." Mem. Geol. Surv.

I898. Rein, Cinment.- "The Geology of the Country around Bournemouth." Mem. Geol. Surv.

Igor. Rowe, A. W.- "The Zones of the White Chalk of the English Coast.-Part II, Dorsel." Proc. Geol. Assoc., vol. xvii, pages I-76.

1906. Strahan, A.- "Guide to the Geological Model of the Isle of Purbeck." Afern. Geol. Surv.

1910. "Geology in the Field." Part II. Bournemouth, pages 277-281. Swanage, pages 399-4r 3 .

\section{EXCURSION TO SOUTHBOROUGH AND TONBRIDGE.}

\author{
Saturday, May 28th, igio. \\ Director: E. W. HaNDCOCK, B.Sc., F.G.S. \\ Excursion Secretary: A. C. Young. \\ (Report by The Director.)
}

THE party, numbering 32 , reached Southborough Station at 3.45 , and at once proceeded to the extensive excavation made by the High Brooms Brick Company, just outside the station.

Here the Director explained that the magnificent section showed Tunbridge Wells Sand overlying Wadhurst Clay. The line of junction was not very evident, owing to a recent landslip of considerable dimensions, which somewhat obscured the lower part of the section. Water issued in large quantities at various points on the junction line, and one spring was pointed out which had caused much trouble to the authorities of the works, who had now carried the water across the intervening space by iron piping. The rate of flow of the spring was pointed out on leaving the works.

Proc. Geol. Assoc., Vol. XXI, Part io, igio.] 